\title{
Delayed presentation of diencephalic syndrome associated with leptomeningeal dissemination in a child
}

\author{
John Ross Crawford, ${ }^{1}$ Katayoon Shayan, ${ }^{2}$ Michael L Levy ${ }^{3}$
}

${ }^{1}$ Department of Neurosciences and Pediatrics, University of California San Diego,

San Diego, California, USA ${ }^{2}$ Department of Pathology, Rady Children's Hospital, San Diego, California, USA ${ }^{3}$ Department of Neurosurgery, University of California San Diego, San Diego, California, USA

\section{Correspondence to} Dr John Ross Crawford, jrcrawford@ucsd.edu
To cite: Crawford JR, Shayan K, Levy ML. BMJ Case Rep Published online: [please include Day Month Year] doi:10.1136/bcr-2013010265

\section{DESCRIPTION}

A 7-year-old girl presented to our hospital with a history of failure to thrive since 1 year of age. Her prior workup included negative serum and stool studies to exclude gastrointestinal, metabolic and endocrinological causes. She has mild speech delay, but otherwise had achieved all her developmental milestones. On admission, she was extremely cachectic weighing $11 \mathrm{~kg}(<1$ st percentile) and a head circumference of $49 \mathrm{~cm}$ (5th percentile). Neurological examination was significant for bilateral papilloedema, optic nerve pallor and peripheral visual field deficits. MRI of the brain revealed a large contrast-enhancing suprasellar tumour with significant hydrocephalus (figure 1A). Areas of leptomeningeal enhancement along the dorsal brainstem prompted spinal MRI that showed diffuse leptomeningeal metastatic disease (figure 1). The patient underwent near total resection of the suprasellar mass where pathology was consistent with a juvenile pilocytic astrocytoma with pilomyxoid features (figure 2). Postoperatively, she exhibited signs of hypothalamic dysfunction including hypothermia, hypotension, bradycardia, diabetes insipidus and near complete visual loss.

Diencephalic syndrome was first recognised in 1951 as a constellation of severe emaciation and preserved linear growth velocity in children associated with hypothalamic tumours. ${ }^{1}$ Treatment of hypothalamic-chiasmatic tumours with chemotherapy may result in weight gain that correlates with tumour shrinkage in some cases. ${ }^{2}$ Leptomeningeal metastatic disease has been reported in children with low-grade suprasellar astrocytomas, and

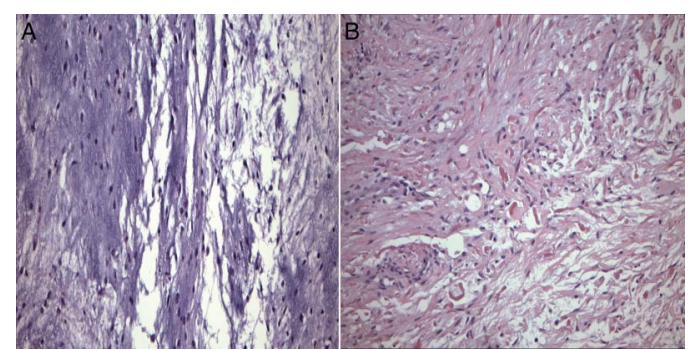

Figure 2 (A) H\&E-stained tumour reveals extensive myxoid background with low cellularity. (B) Adjacent areas have a biphasic appearance with abundant Rosenthal fibres and eosinophilic granular bodies (B), consistent with a diagnosis of pilocytic astrocytoma with pilomyxoid features ( $\times 40$ magnification).

\section{Learning points/take home message}

- Failure to thrive may be an early manifestation of a hypothalamic tumour in the absence of enlarging head circumference.

- Diencephalic syndrome may be associated with significant neurological and endocrinological side effects at presentation and post-treatment.

- Low-grade hypothalamic/chiasmatic astrocytomas are capable of leptomeningeal dissemination that may warrant MRI spine surveillance neuroimaging.

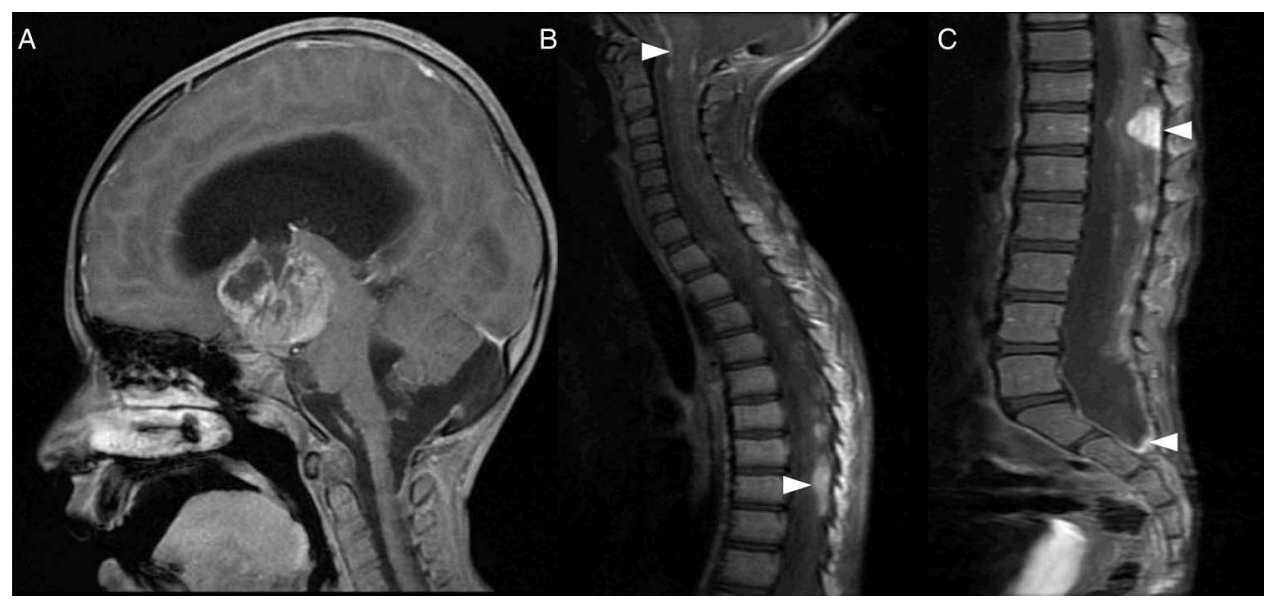

Figure 1 (A) Sagittal T1 postgadolinium MRI brain demonstrates a large suprasellar contrast enhancing neoplasm with associated hydrocephalus. (B and C) Sagittal T1 postgadolinium MRI spine reveals multiple areas of leptomeningeal tumour spread (arrows). 
therefore a screening MRI spine is recommended at diagnosis. ${ }^{3}$ Our case highlights the importance of including diencephalic tumours in the differential diagnosis and workup of patients with failure to thrive of unknown aetiology.

Contributors All authors have contributed equally to the design and preparation of the manuscript.

\section{Competing interests None.}

Patient consent Obtained.
Provenance and peer review Not commissioned; externally peer reviewed.

\section{REFERENCES}

1 Russell AA. Diencephalic syndrome of emaciation in infancy and childhood. Arch Dis Child 1951;26:274

2 Gropman AL, Packer RJ, Nicholson HS, et al. Treatment of diencephalic syndrome with chemotherapy. Cancer 1998;83:166-72.

3 Perilongo G, Carollo C, Salviati L, et al. Diencephalic syndrome and disseminated juvenile pilocytic astrocytomas of the hypothalamic-optic chiasm region. Cancer 1997;80:142-6.

Copyright 2013 BMJ Publishing Group. All rights reserved. For permission to reuse any of this content visit

http://group.bmj.com/group/rights-licensing/permissions.

BMJ Case Report Fellows may re-use this article for personal use and teaching without any further permission.

Become a Fellow of BMJ Case Reports today and you can:

- Submit as many cases as you like

- Enjoy fast sympathetic peer review and rapid publication of accepted articles

- Access all the published articles

- Re-use any of the published material for personal use and teaching without further permission

For information on Institutional Fellowships contact consortiasales@bmjgroup.com

Visit casereports.bmj.com for more articles like this and to become a Fellow 